\title{
Syntheses, structures and cytotoxicity of cobalt(II) complexes with 4'-chloro-2,2':6',2"'-terpyridine
}

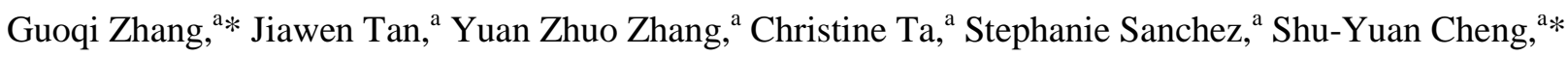 \\ James A. Golen, ${ }^{\mathrm{b}}$ and Arnold L. Rheingold ${ }^{\mathrm{b}}$ \\ ${ }^{a}$ Department of Sciences, John Jay College and the Graduate Center, The City University of New York, New York, \\ NY 10019, United States \\ ${ }^{b}$ Department of Chemistry, University of California, San Diego, La Jolla, CA 92093, United States \\ *Corresponding authors. Email address: guzhang@jjay.cuny.edu (G. Zhang); shcheng@jjay.cuny.edu (S. Cheng)
}

\begin{abstract}
Three cobalt(II) complexes based on 4'-chloro-2,2':6',2"-terpyridine (4'-Cltpy) have been synthesized and structurally characterized by X-ray crystallography. The reaction with a 1:1 metal-to-ligand ratio in a mixed $\mathrm{CH}_{2} \mathrm{Cl}_{2}-\mathrm{MeOH}$ solvent afforded the mononuclear complex $\mathrm{Co}\left(4^{\prime}-\mathrm{Cltpy}\right) \mathrm{Cl}_{2}$ (1) that mimicks the previously reported $\mathrm{Cu}\left(4^{\prime}-\mathrm{Cltpy}\right) \mathrm{Cl}_{2}$, while altering the metal-to-ligand ratio to $2: 1$ under the same reaction conditions resulted in the formation of a different complex with a component of [Co(4'Cltpy)Cl $\left.\mathrm{Cl}_{2}\right]\left[\mathrm{Co}_{2}(4 \text {-Cltpy })_{2} \mathrm{Cl}_{4}\right]$ (2), based on single crystal X-ray structural analysis. The presence of both a mononuclear molecule $\mathrm{Co}\left(4\right.$ '-Cltpy) $\mathrm{Cl}_{2}$ and dinuclear Cl-bridging $\mathrm{Co}_{2}\left(4^{\prime}-\mathrm{Cltpy}\right)_{2} \mathrm{Cl}_{4}$ in 2 was revealed. The replacement of $\mathrm{CoCl}_{2}$ with $\mathrm{Co}(\mathrm{SCN})_{2}$ under the same reaction conditions as for $\mathbf{1}$ gave a similar mononuclear $\mathrm{Co}\left(4^{\prime}-\mathrm{Cltpy}\right)(\mathrm{SCN})_{2}$ (3). The cobalt(II) complexes along with the known copper analogue 4 were investigated for their in-vitro cytotoxic activity towards two human cancer cell lines, the human breast cancer (MCF-7) and leukemia (K562) cells, and distinct cytotoxicity was observed.
\end{abstract}

Keywords: Cobalt(II); 4'-Chloro-2,2':6',2"-terpyridine; Dinuclear complex; Crystal structure; Cytotoxicity

\section{Introduction}

Medicinal inorganic chemistry has become an increasingly important research area, since the observation and validation of cisplatin as an effective clinic anticancer agent in humans [1-3]. Because of the rich coordination chemistry of metals in combination with organic ligands, the involvement of metals in modern medicinal chemistry provides additional opportunities for the design of novel therapeutic drugs 
that were not accessible to pure organic molecules [4,5]. It is believed that both the coordinated metal centers and organic ligands play crucial roles in interacting with DNA of certain targeting cancer cells, therefore, the rational design of biologically active metal-organic coordination compounds containing suitable organic ligands and metal ions is crucial for their anticancer activity [6]. Besides platinum(II) complexes that were extensively explored, recent studies have indicated that base metal complexes of $\mathrm{Cu}$, $\mathrm{Co}, \mathrm{Fe}$ and $\mathrm{Ni}$ with a variety of organic ligands can be promising candidates of chemotherapeutic drugs for various human cancers [7-10].

4'-Chloro-2,2':6',2"-terpyridine (4'-Cltpy, Scheme 1) is a well-known and commercially available member in the tpy family whose coordination chemistry has been extensively investigated, since it was initially introduced in 1990 [11]. Both mono- and bis-ligand transition metal complexes M(4'-Cltpy) $\mathrm{X}_{2}$ and $\mathrm{M}\left(4^{\prime}-\mathrm{Cltpy}\right)_{2}$ (anion $)_{2}\left(\mathrm{M}=\mathrm{Mn}^{\mathrm{II}}, \mathrm{Fe}^{\mathrm{II}}, \mathrm{Ni}^{\mathrm{II}}, \mathrm{Zn}^{\mathrm{II}}, \mathrm{Cd}^{\mathrm{II}}\right.$, or $\mathrm{Ru}^{\mathrm{II}} ; \mathrm{X}=$ halogen $)$ were revealed in a few recent reports, with respect to their single-crystal structural analysis[12]. We have recently reported the synthesis, structures and catalytic properties of novel $\mathrm{Cu}^{\mathrm{II}}$ and mixed-valent $\mathrm{Cu}^{\mathrm{I}} \mathrm{Cu}^{\mathrm{II}}$ complexes of 4 '-Cltpy, with a focus on their structure-activity relationship in catalysis [13]. However, cobalt complexes of 4'Cltpy were little explored and known examples include homoleptic complexes $\mathrm{Co}^{\mathrm{II}}\left(4^{\prime}-\mathrm{Cltpy}\right)_{2}$ (anion) $)_{2}$ and a cobalt(III) complex $\mathrm{Co}^{\mathrm{III}}$ (4'-Cltpy) $\mathrm{Cl}_{3}$ that was structurally characterized [14]. As part of our ongoing studies on the antitumor activity of small molecular coordination compounds [15], we explored the molecular structures of several new $\mathrm{Co}^{\mathrm{II}}$ complexes, and evaluated their cytotoxicity against the human breast cancer (MCF-7) and leukemia (K562) cell lines.

During the past decade, copper complexes have received more attention in the biomedical area, and a plethora of new structures have been reported and exploited for the applications as anticancer agents [16], compared to the cobalt complexes that were studies till to date [17]. Herein, we wish to report the syntheses and crystal structures of three cobalt(II) complexes based on 4'-Cltpy, namely $\mathrm{Co}\left(4^{\prime}-\mathrm{Cltpy} \mathrm{Cl}_{2}\right.$ (1), $\left[\mathrm{Co}\left(4^{\prime}-\mathrm{Cltpy}\right) \mathrm{Cl}_{2}\right]\left[\mathrm{Co}_{2}\left(4^{\prime}-\mathrm{Cltpy}\right)_{2} \mathrm{Cl}_{4}\right]$ (2) and $\mathrm{Co}\left(4^{\prime}-\mathrm{Cltpy}\right)(\mathrm{SCN})_{2}(\mathbf{3})$, as well as their cytotoxic activity towards two kinds of human cancer cells, in contrast to that of the known $\mathrm{Cu}(4$ '-Cltpy $) \mathrm{Cl}_{2}(\mathbf{4})$.

(Insert Scheme 1)

\section{Experimental Section}

\subsection{General}

Solvents, 4'-chloro-2,2':6',2"-terpyridine and metal salts were purchased from Sigma-Aldrich in the US. All reactions were performed under ambient conditions. Solution electronic absorption spectra were recorded on a Shimadzu UV1800 spectrophotometer, and FT-IR spectra were measured on a Shimadzu 8400S instrument with solid samples using a Golden Gate ATR accessory. FAB-MS spectra were 
recorded on a JOEL HX110 mass spectrometer using FAB (fast atom bombardment) technique. Elemental Analysis was performed by Midwest Microlab LLC in Indianapolis. $\mathrm{Cu}\left(4^{\prime}-\mathrm{Cltpy}\right) \mathrm{Cl}_{2}(4)$ was prepared as reported previously [24].

\subsection{Synthesis of $\mathbf{1}$}

To a stirred solution of 4'-Cltpy $(26.7 \mathrm{mg}, 0.100 \mathrm{mmol})$ in $\mathrm{CH}_{2} \mathrm{Cl}_{2}\left(10 \mathrm{~cm}^{3}\right)$ was added dropwise a methanolic solution $\left(5 \mathrm{~cm}^{3}\right)$ of $\mathrm{CoCl}_{2} \cdot 6 \mathrm{H}_{2} \mathrm{O}(23.7 \mathrm{mg}, 0.100 \mathrm{mmol})$ at room temperature, the resulting green solution was stirred for $10 \mathrm{~min}$, then filtered. The filtrate was allowed to slowly evaporate at room temperature for 3 days, during which time green plates had formed and were collected by decanting the solvent, washed with methanol and dried in air. Yield: $32.5 \mathrm{mg}(81.7 \%)$. FT-IR (solid, $\mathrm{cm}^{-1}$ ): 1590s, 1553s, 1469s, 1415s, 1340w, 1290w, 1245m, 1118s, 1051w, 1016s, 898m, 830s, 793s, 726m, 687w, $634 \mathrm{~m}$. Found C 45.33, H 2.60, N 10.54; $\mathrm{C}_{15} \mathrm{H}_{10} \mathrm{Cl}_{3} \mathrm{CoN}_{3}$ (397.55) requires C 45.32, $\mathrm{H} 2.54, \mathrm{~N} 10.57 \%$.

\subsection{Synthesis of 2}

The procedure was similar to that for 1 , except the use of 2.0 equiv. $\mathrm{CoCl}_{2} \cdot 6 \mathrm{H}_{2} \mathrm{O}(47.4 \mathrm{mg}, 0.200 \mathrm{mmol})$. Blue-green blocks were isolated in $76.7 \%$ yield $\left(30.5 \mathrm{mg}\right.$ ). FT-IR (solid, $\mathrm{cm}^{-1}$ ): $3047 \mathrm{br}, 1588 \mathrm{~s}, 1554 \mathrm{~s}$, 1470s, 1415s, 1340w, 1299w, 1245m, 1161w, 1119m, 1044w, 1015s, 898w, 860w, 822m, 793s, 745m, $727 \mathrm{~m}, 688 \mathrm{~m}, 654 \mathrm{~m}$. Found C 44.95, H 2.45, N 10.39; $\mathrm{C}_{15} \mathrm{H}_{10} \mathrm{Cl}_{3} \mathrm{CoN}_{3}$ (397.55) requires C 45.32, H 2.54, N $10.57 \%$.

\subsection{Synthesis of 3}

The procedure was similar to that for 1 , except the replacement of $\mathrm{CoCl}_{2} \cdot 6 \mathrm{H}_{2} \mathrm{O}$ with $\mathrm{Co}(\mathrm{SCN})_{2}(17.5 \mathrm{mg}$, $0.100 \mathrm{mmol}$ ). Red-brown blocks suitable for X-ray diffraction analysis were obtained after 5 days. Yield: $37.2 \mathrm{mg}$ (84.0\%). FT-IR (solid, $\mathrm{cm}^{-1}$ ): 3054w, 2070s, 1588s, 1551s, 1471s, 1417s, 1338w, 1302w, 1245m, 1588m, 1118m, 1043w, 1014m, 831m, 790s, 746w, 726s, 687m, 654m. FAB-MS: m/z 384.0 [M-SCN] ${ }^{+}$ (calc. 384.0). Found C 46.64, H 2.07, N 15.68; $\mathrm{C}_{17} \mathrm{H}_{10} \mathrm{ClCoN}_{5} \mathrm{~S}_{2}$ (442.81) requires C 46.11, H 2.28, N $15.82 \%$.

\subsection{Crystal Structure Determinations}

Suitable single crystals of 1-3 were mounted on Cryoloops with Paratone-N oil. Data were collected at $100 \mathrm{~K}$ with a Bruker APEX II CCD using Mo-K $\alpha$ radiation and corrected for absorption with SADABS and structures solved by direct methods. All non-hydrogen atoms were refined anisotropically by fullmatrix least squares on $\mathrm{F}^{2}$. Hydrogen atoms were found from Fourier difference maps and refined 
isotropically, otherwise they were placed in calculated positions with appropriate riding parameters. Refinement details are summarized as follows.

1: $\mathrm{C}_{15} \mathrm{H}_{10} \mathrm{Cl}_{3} \mathrm{CoN}_{3}, M=397.54$, green plate, monoclinic, space group $P 2(1) / \mathrm{c}, a=9.9327(17), b=$ 8.8085(14), $c=17.353(3) \mathrm{A}^{\circ}, \beta=99.370(4)^{\circ}, U=1498.0(4) \mathrm{A}^{\circ 3}, Z=4, D_{c}=1.763 \mathrm{Mg} \mathrm{m}^{-3}, \mu(\mathrm{Mo}-\mathrm{K} \alpha)=$ $1.677 \mathrm{~mm}^{-1}, T=100(2) \mathrm{K}$. Total 13980 reflections, 3318 unique, $R_{\mathrm{int}}=0.046$. Refinement of 2718 reflections (199 parameters) with $I>2 \sigma(I)$ converged at final $R_{1}=0.0297\left(R_{1}\right.$ all data $\left.=0.0425\right), w R_{2}=$ $0.0675\left(w R_{2}\right.$ all data $\left.=0.0735\right)$, gof $=1.010$.

2: $\mathrm{C}_{15} \mathrm{H}_{10} \mathrm{Cl}_{3} \mathrm{CoN}_{3}, M=397.54$, blue-green block, monoclinic, space group $P 2(1) / \mathrm{c}, a=14.442(2), b=$ $13.1758(14), c=17.290(3) \mathrm{A}^{\circ}, \beta=112.739(4)^{\circ}, U=3034.2(7) \mathrm{A}^{\circ 3}, Z=8, D_{c}=1.741 \mathrm{Mg} \mathrm{m}^{-3}, \mu(\mathrm{Mo}-\mathrm{K} \alpha)$ $=1.656 \mathrm{~mm}^{-1}, T=100(2) \mathrm{K}$. Total 36765 reflections, 6215 unique, $R_{\mathrm{int}}=0.1148$. Refinement of 3841 reflections (397 parameters) with $I>2 \sigma(I)$ converged at final $R_{1}=0.0562\left(R_{1}\right.$ all data $\left.=0.1133\right), w R_{2}=$ $0.0906\left(w R_{2}\right.$ all data $\left.=0.1082\right)$, gof $=1.009$.

3: $\mathrm{C}_{17} \mathrm{H}_{10} \mathrm{ClCoN}_{5} \mathrm{~S}_{2}, M=442.80$, red block, monoclinic, space group $C 2 / \mathrm{c}, a=15.024(2), b=10.3792(14)$, $c=12.4699(16) \mathrm{A}^{\circ}, \beta=106.215(3)^{\circ}, U=1867.2(4) \mathrm{A}^{\circ 3}, Z=4, D_{c}=1.575 \mathrm{Mg} \mathrm{m}^{-3}, \mu(\mathrm{Mo}-\mathrm{K} \alpha)=1.296$ $\mathrm{mm}^{-1}, T=100(2) \mathrm{K}$. Total 13256 reflections, 1931 unique, $R_{\text {int }}=0.0892$. Refinement of 1771 reflections (199 parameters) with $I>2 \sigma(I)$ converged at final $R_{1}=0.0309\left(R_{1}\right.$ all data $\left.=0.0346\right), w R_{2}=0.0809\left(w R_{2}\right.$ all data $=0.0838)$, gof $=1.029$.

\subsection{Cytotoxicity Measurement by Trypan Blue Exclusion Assay}

Human breast cancer (MCF-7) and human leukimia (K562) cells were obtained from Sigma Aldrich Co. (St. Louis, MO). MCF-7 cells were cultured within completed media containing Dulbecco's modified eagle's medium (DMEM) supplemented with $10 \%$ fetal bovine serum and $50 \mu \mathrm{g} / \mathrm{mL}$ gentamicin in a humidified atmosphere a $5 \%$ humidified $\mathrm{CO}_{2}$ atmosphere at $37^{\circ} \mathrm{C}$. $\mathrm{K} 562$ cells were cultured within RPMI 1640 containing $10 \%$ fetal bovine serum, $50 \mu \mathrm{g} / \mathrm{mL}$ gentamicin, and $2 \mathrm{mM}$ glutamine in a $5 \%$ humidified $\mathrm{CO}_{2}$ atmosphere at $37^{\circ} \mathrm{C}$. For chemical treatment, cells were subcultured into 24-well plate a day prior to the experiment. Cells were about medium density ( $80 \%$ confluence) for chemical treatments. Compounds were prepared as a $100 \mathrm{mM}$ stock in dimethylsulfoxide (DMSO), then diluted in the culture media to various concentrations $(0$ to $250 \mathrm{uM}) 15$ minutes prior chemical treatments. Cytotoxicity of samples 1-4 were determined using trypan blue exclusion assay. All treatments were performed in triplicate. After 48 hours chemical exposure, cells from each well were harvested and stained with $0.4 \%$ trypan blue solution in 1:1 ratio and counted by Countess ${ }^{\mathrm{TM}}$ Automated Cell Counter (Life Technologies). Percentage of cell viability for each chemical concentration was used to calculate LD50.

\section{Results and Discussion}




\subsection{Synthesis and Structural Characterization}

The reaction of 4'-Cltpy with 1.0 equiv. cobalt(II) dichloride in a $\mathrm{CH}_{2} \mathrm{Cl}_{2}-\mathrm{MeOH}$ solution at room temperature resulted in the isolation of green plates of $\mathbf{1}$ after slow evaporation of solvents in three days. $\mathbf{1}$ was characterized as an empirical formula of $\mathrm{Co}\left(4^{\prime}-\mathrm{Cltpy}\right) \mathrm{Cl}_{2}$ by elemental analysis and its structure was determined by single-crystal X-ray diffraction analysis. Although the crystal structure of a cobalt(III) complex $\mathrm{Co}^{\mathrm{III}}$ (4'-Cltpy)Cl $\mathrm{Cl}_{3}$ was reported recently [14], that of $\mathrm{Co}^{\mathrm{II}}\left(4\right.$ '-Cltpy) $\mathrm{Cl}_{2}$ is unprecedented. Crystalline 1 is isostructural to the known $\mathrm{Cu}^{\mathrm{II}}\left(4^{\prime}-\mathrm{Cltpy} \mathrm{Cl}_{2}(\mathbf{4})\right.$ and crystallizes in the monoclinic space group $P 2(1) / c$. An ORTEP representation of an independent molecule of $\mathbf{1}$ in the asymmetric unit is showed in Fig. 1a and the bond parameters that are unexceptional are listed in the caption. As seen in Fig. 1a, the $\mathrm{Co}^{\mathrm{II}}$ center coordinates to one 4'-Cltpy molecule with the convergent nitrogen donors, and two chloride anions saturate the coordination sphere of the $\mathrm{Co}$ II center. The geometry around the $\mathrm{CoN}_{3} \mathrm{Cl}_{2}$ core is determined by the distortion parameter $\tau$ value according to Addison's method [18]. The $\tau$ value was calculated to be 1.25 from the equation, $\tau=(\theta 1 \square \theta 2) / 60$ (where $\theta 1$ and $\theta 2$ are the largest angles in the coordination sphere, $\tau=0$ represents a perfect square pyramid, and $\tau=1$ indicates a perfect trigonal bipyramid), suggesting a distorted trigonal bipyramid geometry of $\mathrm{Co}^{\mathrm{II}}$. It is noted that the distance of Co$\mathrm{N} 2$ bond between cobalt atom and the central pyridine-N of tpy domain is slightly shorter (2.0701(17) $\AA$ ) than other Co-N bonds. The three pyridine rings are essentially coplanar, due to the metal binding in the $\mathrm{N}_{3}$ cavity; the distortion angles of adjacent pyridine rings are only $1.14^{\circ}$ and $1.41^{\circ}$, respectively. In the crystal packing mode molecules of $\mathbf{1}$ pack along the crystallographic $a$ axis in an alternate head-to-tail manner through significant intermolecular $\pi \ldots \pi$ stacking interactions between the tpy domains of the complexes, forming a columnar packing mode as illustrated in Fig. 1b. The shortest centroid...centroid distance for the $\pi$-stacking is $3.265 \AA$.

(Insert Fig. 1)

Interestingly, it was found that changing the reaction ratio of $\mathrm{Co}^{\mathrm{II}}$-ligand led to the formation of a new coordination assembly. Thus, upon reacting 4'-Cltpy with 2.0 equiv. cobalt(II) dichloride under the same conditions as for $\mathbf{1}$, blue-green crystals of $\mathbf{2}$ were obtained from the reaction mixture after slow evaporation. 2 features the same molecular component as $\mathbf{1}$ as revealed by elemental analysis, however, it was confirmed that two independent molecules of both mononuclear 1 and a dimeric $\mathrm{Co}_{2}\left(4^{\prime}-\mathrm{Cltpy}_{2} \mathrm{Cl}_{4}\right.$ are present in the crystals of $\mathbf{2}$ based on single crystal X-ray structural analysis. The partial formation of dimeric complexes in $\mathbf{2}$ might be attributed to the aggregation of molecules of monomer $\mathbf{1}$ induced by the increased concentration of metal salt in the solution. $\mathbf{2}$ also crystallizes in the monoclinic space group $P 2(1) / c$, yet other cell parameters are different from those of $\mathbf{1}$. Both the monomeric and dimeric 
molecules in complex 2 are exhibited in Fig. 2a. The dimeric complex containing the Co1 center is centrosymmetric and only one half of the molecule is independent in the asymmetric unit, the second half is generated by the symmetry operation (code: $i=2-\mathrm{x}, 1-\mathrm{y}, 1-\mathrm{z}$ ). The monomer with a Co2 center is essentially identical to the structure of $\mathbf{1}$, having a distortion parameter $\tau=1.24$ around the pentacoordinate $\mathrm{Co}^{\mathrm{II}}$ center, although the pyridine rings of ligands are slightly more distorted with respect to each other (the distortion angles are $2.50^{\circ}$ and $4.47^{\circ}$, respectively). In the dimer of Co1, cobalt(II) is hexacoordinate with a slightly distorted octahedral geometry, although the distance between Co1 and the bridging $\mathrm{Cl}$ atom is obviously longer than others $\left(\mathrm{Co}^{-} \mathrm{Cl}_{2}{ }^{\mathrm{i}}=2.759 \AA\right)$. The Co-N distances around two distinct cobalt(II) centers are close, while the regular $\mathrm{Co}-\mathrm{Cl}$ bond lengths vary from 2.4160(15) and 2.3219(14) $\AA$ for Co1 to 2.3051(15) and 2.2748(15) $\AA$ for Co2. In addition, the Cl-Co-Cl angles in two molecules differ significantly $\left(98.75(5)^{\circ}\right.$ vs $\left.109.07(5)^{\circ}\right)$. The coexistence of both monomer and dimer in crystals of $\mathbf{2}$ thus led to a remarkably different three-dimensional molecular packing mode as shown in Fig. 2 b, in contrast to that in $\mathbf{1}$. In $\mathbf{2}$, significant $\pi$-stacking interactions were observed between the tpy domains of monomer with monomer, monomer with dimer, and dimer with dimer, and the shortest interatomic distances between these tpy domains are 3.378, 3.387 and $3.396 \AA$, respectively.

\section{(Insert Fig. 2)}

The synthetic procedure for $\mathbf{1}$ was then applied to the synthesis of another cobalt(II) complex $\mathbf{3}$ through the stoichiometric reaction between 4'-Cltpy and cobalt(II) dithiocyanate [18]. Accordingly, red crystals of $\mathbf{3}$ was isolated in good yield and structurally determined by X-ray crystallography [19]. The bulk sample was characterized by IR and mass spectra, and elemental analysis, and the empirical formula of $\mathrm{Co}(4$-Cltpy $)(\mathrm{SCN})_{2}$ was defined. Unlike $\mathbf{1}$ and $\mathbf{2}, \mathbf{3}$ crystallizes in the monoclinic space group $C 2 / \mathrm{c}$. The molecule of $\mathbf{3}$ is monomeric with one $\mathrm{Co}^{\text {II }}$ center and interestingly the molecule itself is $C 2$ symmetric (Fig. 3a). In the asymmetric unit of $\mathbf{3}$, one half of the complex molecule was independent and the other half was generated by symmetry operation (code: $-x+1, y,-z+3 / 2$ ). The cobalt center is penta-coordinate with five nitrogen atoms including three from the 4'-Cltpy ligand and two from thiocyanate anions, being in a distorted trigonal bipyramid environment $(\tau=1.29)$. The Co- $\mathrm{N}_{\text {pyridine }}$ bond lengths are similar to those in $\mathbf{1}$ and $\mathbf{2}$, while the Co- $\mathrm{N}_{\text {thiocyanate }}$ bonds are relatively shorter. The molecular packing of $\mathbf{3}$ shows columnar arrangement similar to that found in $\mathbf{1}$ through $\pi$-stacking interactions between tpy domains along the crystallographic $c$ axis (Fig. 3b), although a little longer $\pi \ldots \pi$ distance (3.579 ̊) was observed.

(Insert Fig. 3) 


\subsection{Cytotoxicity Studies}

To evaluate the cytotoxic activity of diverse cobalt complexes 1-3 and compare the results with the copper(II) analogue 4, we next performed the in-vitro cytotoxicity measurements on these metal complexes. Two kinds of cancer cell arrays were chosen for this study, the human breast cancer cells (MCF-7) and human leukemia cells (K562). The $\mathrm{LC}_{50}$ values given in Table 1 show that the Co ${ }^{\mathrm{II}}$ complexes 1-3 are generally more cytotoxic against both the MCF-7 and K562 cells after 48 hours treatment as compared to the $\mathrm{Cu}^{\mathrm{II}}$ complex 4 . MCF-7 cells were more susceptible to these $\mathrm{Co}^{\mathrm{II}}$ complexes than the K562 cells. It was also revealed that cobalt(II) complex 3 with thiocyanate groups displayed apparently higher cytotoxicity against the MCF-7 cells than the cobalt(II) complex 1 having chloride counterions. However, complex 1 was found to be more cytotoxic than $\mathbf{3}$ against the K562 cells. In addition, cobalt(II) complex 2 containing a dinuclear cobalt(II) component showed the strongest toxic effect on the K562 cells with a $\mathrm{LC}_{50}$ of $6.7 \pm 0.6 \mu \mathrm{M}$, comparable to other copper or cobalt complexes that were reported in the literature $[16,17]$. The observation would provide valuable insights for the future design of metal-based anticancer drug candidates that can eventually enter clinical trials.

(Insert Table 1)

\section{Conclusion}

In conclusion, cobalt(II) complexes derived from 4'-chloro-2,2':6',2"-terpyridine have been reported. The change of metal-to-ligand ratio was found to affect the structures of the resulting metal complexes upon reacting the ligand with cobalt(II) dichloride. While in $\mathbf{1}$ only mononuclear complex was observed, which is similar to the known copper(II) analogue, 2 contains both monoand di-nuclear cobalt(II)-centered components. In addition, mononuclear complex $\mathbf{3}$ with thiocyanate ligating anions was also isolated and characterized. The cytotoxicity studies on cobalt(II) complexes 1-3 and the copper analogue 4 were carried out and the results revealed that cobalt(II) complexes 1-3 were generally more toxic than the copper(II) complex 4 upon incubating with both MCF-7 and K562 cancer cell lines after 48 hours, and 2 showed the highest cytotoxicity against K562 cells, while 3 was the best inhibitor for MCF-7 cells, indicating significant potential of $\mathrm{Co}^{\mathrm{II}}$-tpy type complexes for applications as anticancer agents.

\section{Acknowledgements}


We gratefully acknowledge the American Chemical Society Petroleum Research Fund (54247-UNI3), the PSC-CUNY Award (67312-0045) from the Research Foundation of the City University of New York, the CUNY Collaborative Incentive Research Grant (CIRG \#2110) and the Program for Research Initiatives for Science Majors (PRISM) at John Jay College funded by the Title V, HSI-STEM and MSEIP programs within the U.S. Department of Education; the PAESMEM program through the National Science Foundation; and New York State's Graduate Research and Teaching Initiative.

\section{References}

[1] B. Rosenberg, L. Van Camp, T. Krigas, Nature, 200 (1965) 698.

[2] B. Rosenberg, L. Van Camp, E. B. Grimley, J. Thomson, J. Biol. Chem. 242 (1967) 1347.

[3] J. J. Wilson, S. J. Lippard, Chem. Rev. 114 (2014) 4470.

[4] T. W. Hambley, Dalton Trans. (2007) 4929.

[5] F. Arnesano, G. Natile, Coord. Chem. Rev. 253 (2009) 2070.

[6] (a) I. Romero-Canelon, P. J. Sadler, Inorg. Chem. 52 (2013) 12276;

(b) J. Chen, J. Stubbe, Nat. Rev. Cancer 5 (2005) 102;

(c) F. Mancin, P. Scrimin, P. Tecilla, U. Tonellato, Chem. Commun. (2005) 2540.

[7] N. Farrel (Ed.), Transition Metal Complexes as Drugs and Chemotherapeutic Agents, Kluwer, Dordrecht, 1989.

[8] B.K. Keppler (Ed.), Metal Complexes in Cancer Therapy, VCH, Weinheim, 1993.

[9] M. Galanski, V.B. Arion, M.A. Jakupec, B.K. Keppler, Curr. Pharm. Des., 9 (2003) 2078.

[10] (a) H. Glasner, E.Y. Tshua, J. Am. Chem. Soc., 133 (2011) 16812;

(b) S.-Y. Lee, A. Hille, C. Frias, B. Kater, B. Bonitzki, S. Wölfl, H. Scheffler, A. Prokop, R. Gust, J. Med. Chem., 53 (2010) 6064 ;

(c) Z. Liu, P.J. Sadler, Acc. Chem. Res., 47 (2014) 1174;

(d) M.U. Raja, J. Tauchman, B. Therrien, G. Suss-Fink, T. Riedel, P.J. Dyson, Inorg. Chim. Acta, 409 (2014) 479.

[11] E. C. Constable, M. D. Ward, J. Chem. Soc., Dalton Trans. (1990) 1405.

[12] (a) J. Beves, E. C. Constable, C. E. Housecroft, M. Neuburger, S. Schaffner, J. A. Zampese, 11 (2008) 1006;

(b) W. You, X.Y. Yang, C. Yao, W. Huang, Acta Crystallogr., Sect. E 64 (2008) m79;

(c) W. Huang, H. Qian, J. Mol. Struct. 874 (2008) 64;

(d)W. Huang, H. Qian, J. Mol. Struct. 832 (2007) 108;

(e) L. A. Saghatforoush, L. Valencia, F. Chalabian, Sh. Ghammamy, Bioinorg. Chem. Appl. (2011) 803292.

[13] G. Zhang, E. Liu, C. Yang, L. Li, J. A. Golen, A. L. Rheingold, Eur. J. Inorg. Chem. (2015) 939. 
[14] (a) E. C. Constable, K. Harris, C. E. Housecroft, M. Neuburger, J. A. Zampese, CrystEngComm 12 (2010) 2949. (b) K. B. Aribia, T. Moehl, S. M. Zakeeruddin, M. Grätzel, Chem. Sci. 4 (2013) 454.

(c) E. C. Constable, K. Harris, C. E. Housecroft, M. Neuburger, J. A. Zampese, Dalton. Trans. 40 (2011) 11441. [15] G. Zhang, C. Ta, S.-Y. Cheng, J. A. Golen, A. L. Rheingold, Inorg. Chem. Commun. 48 (2014) 127.

[16] C. Santini, M. Pellei, V. Gandin, M. Porchia, F. Tisato, C. Marzano, Chem. Rev. 114 (2014) 815 and references therein.

[17] (a) E. M. Mosoarca, I. Pantenburg, R. Tudose, G. Meyer, R. Alexandrova, R. Kalfin, W. Linert, O. Costisor, Med. Chem. 6 (2010) 298;

(b) M. A. Neukamm, A. Pinto, N. Metzler-Nolte, Chem. Commun. (2008) 232.

(c) T. Sarkar, S. Banerjee, A. H. Hussain, RSC Adv. 5 (2015) 16641.

(d) J.-L. Li, L. Jiang, B.-W. Wang, J.-L. Tian, W. Gu, X. Liu, S.-P. Yan, J. Inorg. Biochem. 145 (2015) 19.

(e) K. Das, A. Datta, P.-H. Liu, J.-H. Huang, C.-L. Hsu, W.-T. Chang, B. Machura, C. Sinha, Polyhedron 71 (2014) 85.

[18] A. W. Addison, T. N. Rao, J. Reedijk, J. Van Rijn, G. C.Verschoor, J. Chem. Soc., Dalton Trans. (1984) 1349. 
<smiles>Clc1cc(-c2ccccn2)nc(-c2ccccn2)c1</smiles>

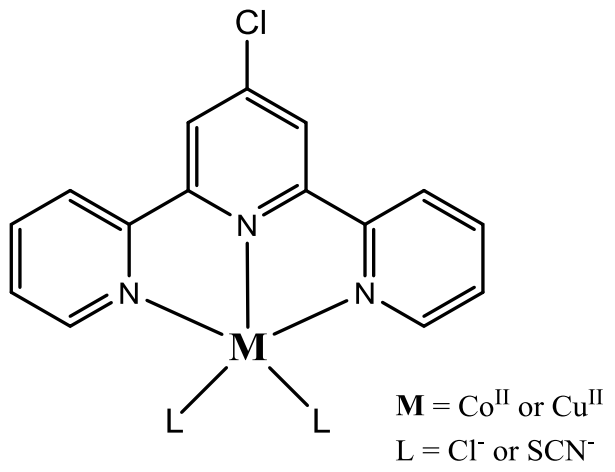

Scheme 1. The structures of 4'-Cltpy and its mononuclear $\mathrm{Co}^{\mathrm{II}}$ or $\mathrm{Cu}^{\mathrm{II}}$ complexes.

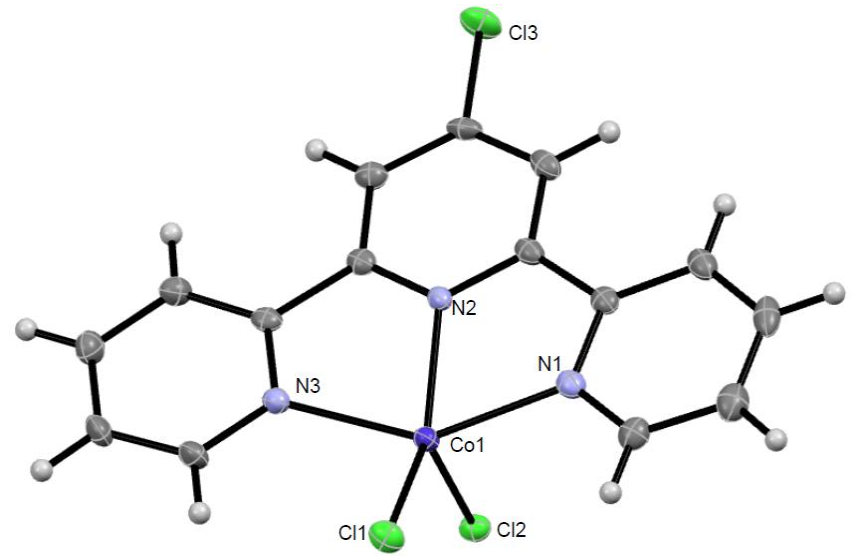

(a)

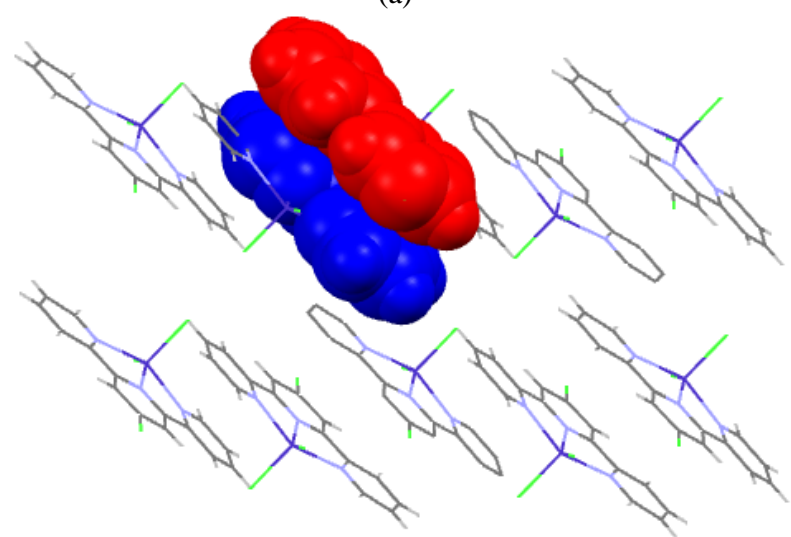

(b)

Fig. 1. (a) The ORTEP structure of $\mathbf{1}$ with ellipsoids plotted at the 50\% probability level. Selected bond parameters: Co1-N1 = 2.1403(19), Co1-N2 = 2.0701(17), Co1-N3 = 2.1332(19), Co1-Cl1 = 2.2830(7), Co1-Cl2 = 2.3264(7) N2-Co1-N1 = 75.22(7), N2-Co1-N3 = 75.55(7), N3-Co1-N1 = 146.56(7), N2-Co1-Cl1 = 150.39(5), N1-Co1-Cl1 = 99.69(5), N3-Co1-Cl1 = 97.69(5), N2-Co1-Cl2 = 94.21(5), N3-Co1-Cl2 = 99.08(5), N1-Co1-Cl2 = 98.92(5), Cl1-Co1$\mathrm{Cl} 2=115.39(2)^{\circ}$. (b) The crystal packing in 1 showing the $\pi$-stacking interaction between tpy domains along the crystallographic $a$ axis, highlighted by red and blue balls. 


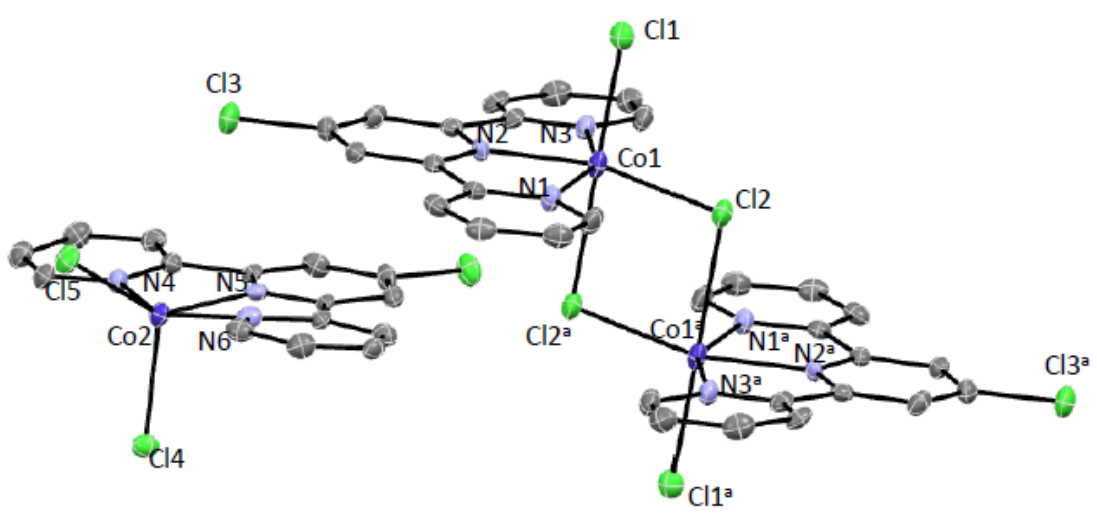

(a)

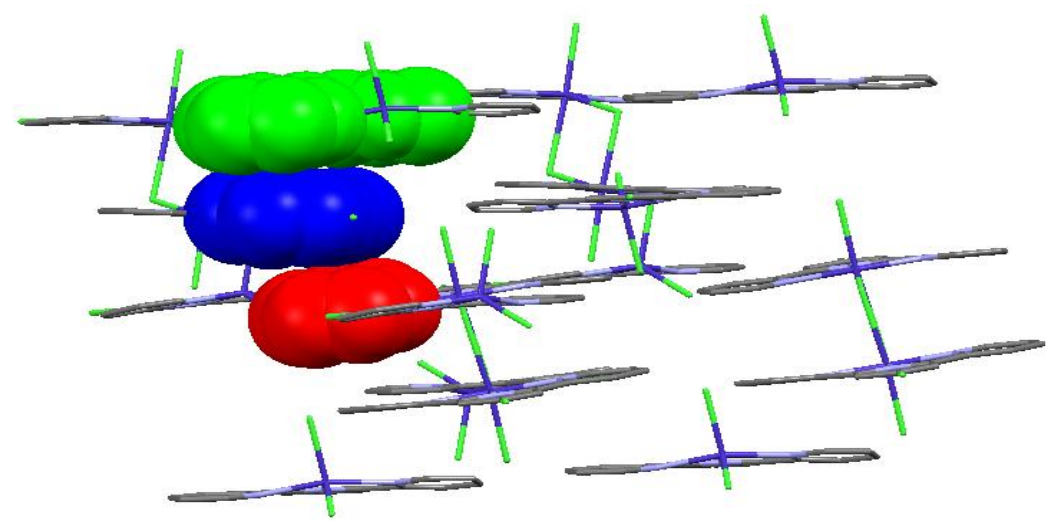

(b)

Fig. 2. The ORTEP representation of two independent molecules and a dimeric unit generated by symmetry operation in unit cell of 2 with ellipsoids plotted at the 50\% probability level. Selected bond parameters: Co1-N1 = 2.141(4), Co1$\mathrm{N} 2=2.067(4), \mathrm{Co} 1-\mathrm{N} 3=2.127(4), \mathrm{Co} 1-\mathrm{Cl} 1=2.4160(15), \mathrm{Co} 1-\mathrm{Cl} 2=2.3219(14), \mathrm{Co} 2-\mathrm{N} 4=2.157(4), \mathrm{Co} 2-\mathrm{N} 5=$ 2.058(4), Co2-N6 = 2.136(4), Co2-Cl4 = 2.3051(15), Co2-Cl5 = 2.2748(15) А̊; Cl1-Co1-Cl2 = 98.75(5), Cl1-Co1-Cl2 ${ }^{\mathrm{i}}$ $=175.56(5), \mathrm{Cl} 4-\mathrm{Co} 2-\mathrm{Cl} 5=109.07(5)^{\circ}$. (b) The three-dimensional molecular packing mode in 2 revealing significant $\pi-$ stacking interactions. Symmetry code: $i=2-\mathrm{x}, 1-\mathrm{y}, 1-\mathrm{z}$. 


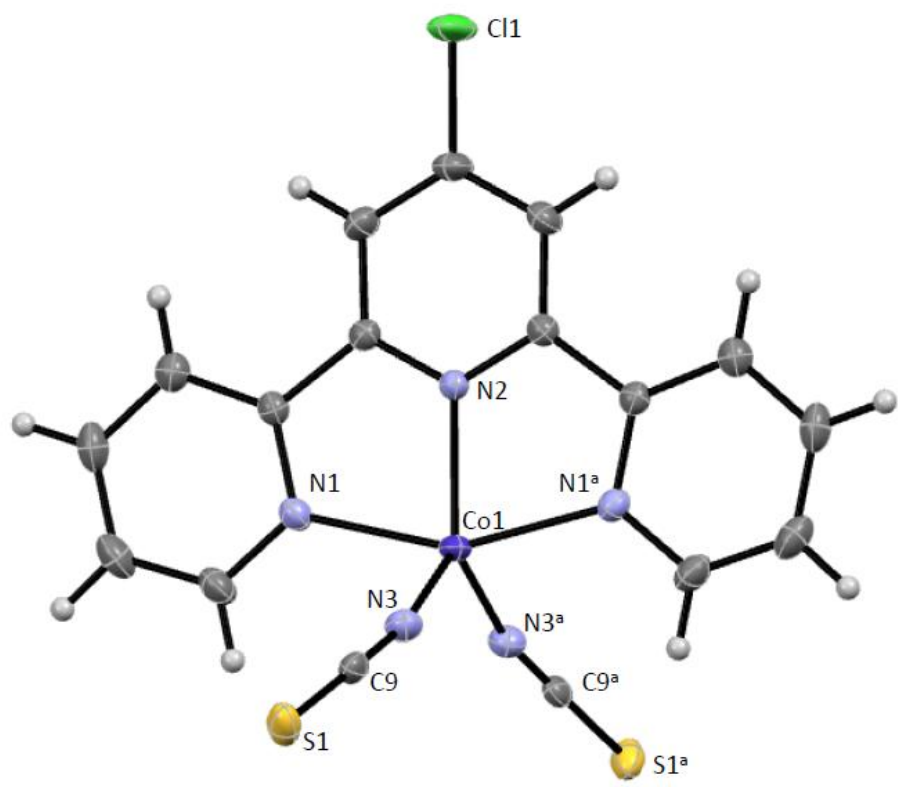

(a)

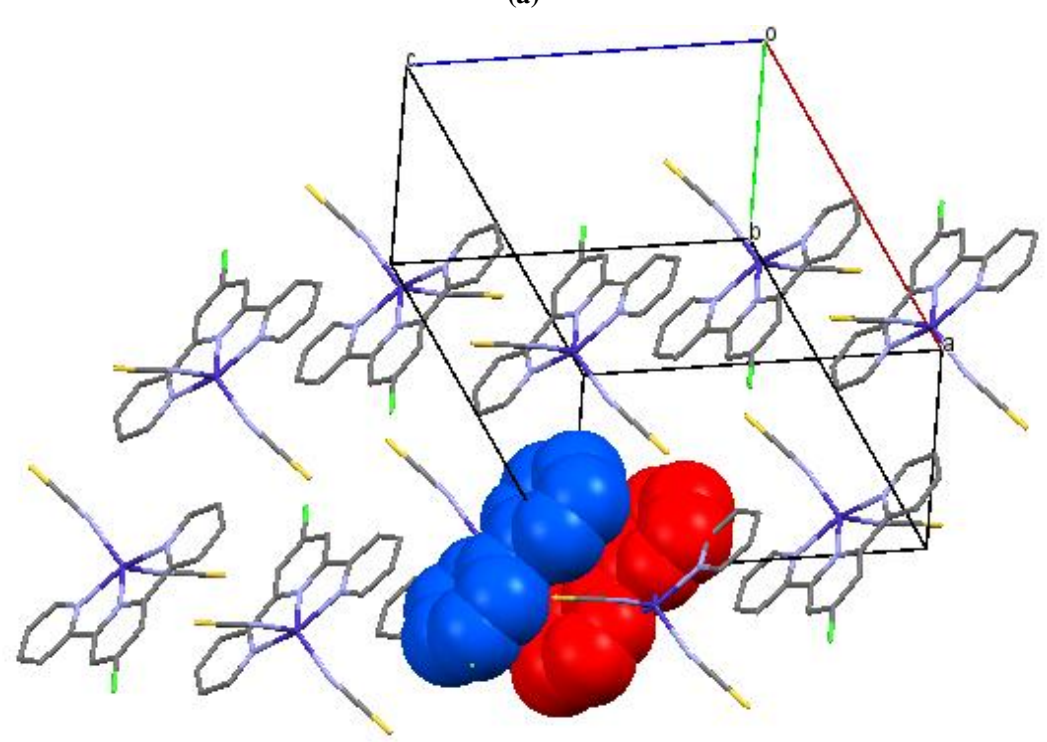

(b)

Fig. 3. The ORTEP structure of $\mathbf{3}$ with ellipsoids plotted at the 50\% probability level. Selected bond parameters: Co1-

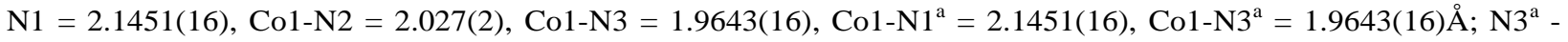
Co1-N3 = 114.71(9), N3-Co1-N2 = 122.65(4), N3 ${ }^{\mathrm{a}}-\mathrm{Co} 1-\mathrm{N} 1=94.15(6), \mathrm{N} 3-\mathrm{Co} 1-\mathrm{N} 1=99.67(6), \mathrm{N} 2-\mathrm{Co} 1-\mathrm{N} 1=$ 77.13(4), N1-Co1-N1 ${ }^{\mathrm{a}}=154.26(8)^{\circ}$. Symmetry codes: $a=-\mathrm{x}+1, \mathrm{y},-\mathrm{z}+{ }^{3} / 2$. (b) The molecular packing in 3 showing the $\pi$-stacking interaction between tpy domains along the crystallographic $c$ axis. 
Table 1. Cytotoxic activity of complexes 1-4 against MCF-7 and K562 cell lines in 48 hours treatment protocol.

\begin{tabular}{ccc}
\hline Compounds & LC $_{50}(\mathrm{MCF}-7)[\mu \mathrm{M}]$ & $\mathrm{LC}_{50}(\mathrm{~K} 562)[\mu \mathrm{M}]$ \\
\hline $\mathbf{1}$ & $24.1 \pm 2.9$ & $67.3 \pm 1.8$ \\
$\mathbf{2}$ & N.A. & $6.7 \pm 0.6$ \\
$\mathbf{3}$ & $6.2 \pm 2.7$ & $145.5 \pm 1.1$ \\
$\mathbf{4}$ & $55.2 \pm 5.1$ & $321.7 \pm 31.1$ \\
\hline
\end{tabular}


Graphical Abstract
Graphical Abstract - Pictogram

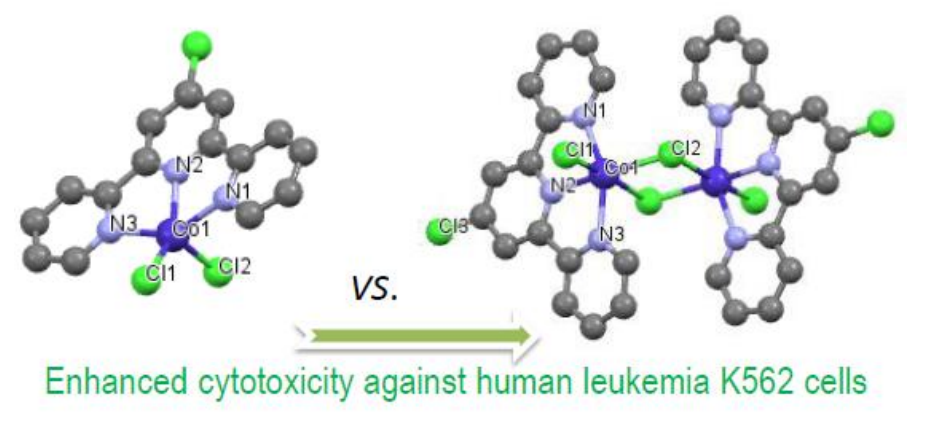

Graphical Abstract
Graphical Abstract - Pictogram

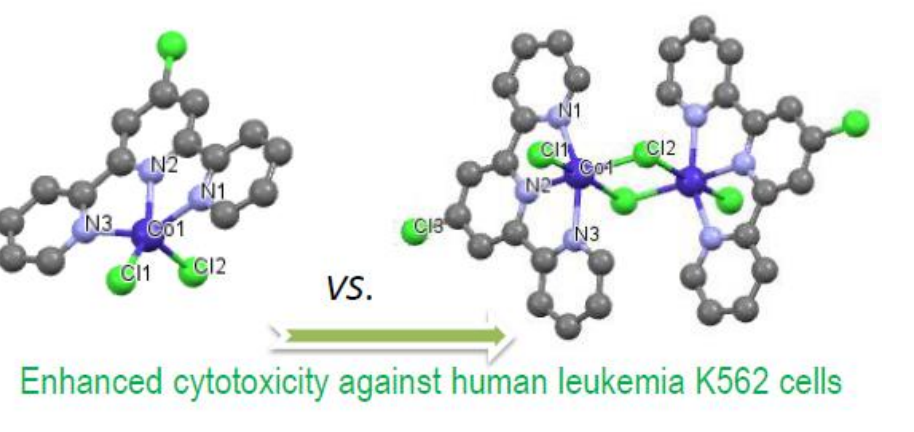

Graphical Abstract
Graphical Abstract - Pictogram

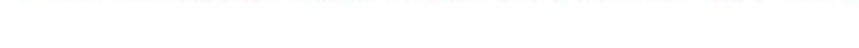

.

.

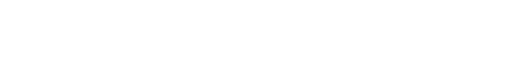
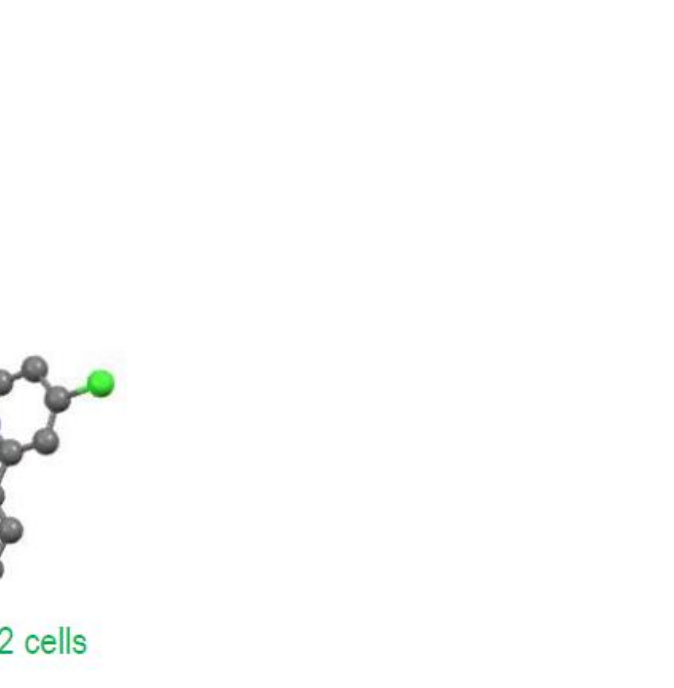

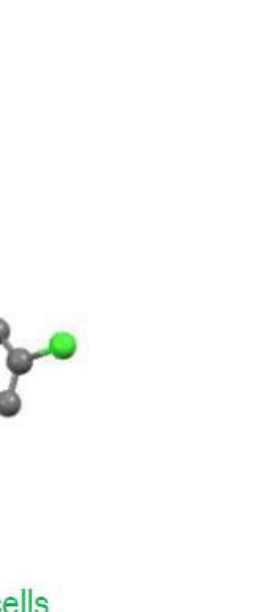

s

.

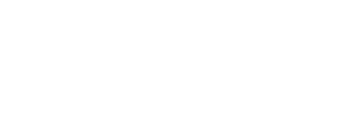
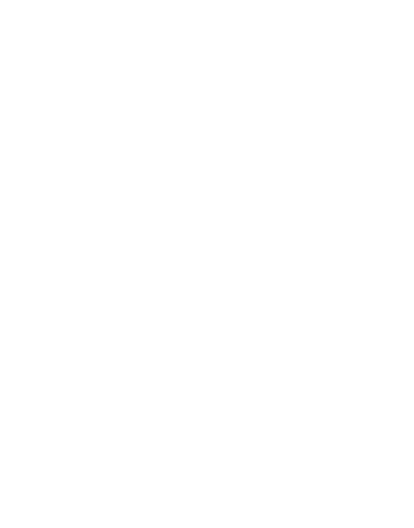

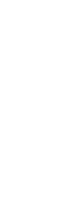

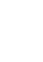

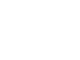

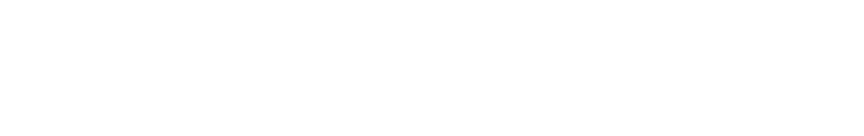


Graphical abstract

\section{Graphical Abstract - Synopsis}

Three diverse cobalt(II) complexes based on 4'-chloro-2,2':6',2"-terpyridine have been synthesized and structurally characterized, and their in-vitro cytotoxic activity against human breast cancer (MCF-7) and leukemia (K562) cells were investigated. 